\title{
Application and Exploration of Micro-lecture in Integrated English Teaching-A Case Study in University of Chinese Academy of Social Sciences
}

\author{
YANG Chun \\ University of Chinese Academy of Social Sciences, Beijing, China
}

\begin{abstract}
In integrated English teaching, the application of micro-lectures has transformed students' learning style, increased their interest in English learning, and greatly improved their study efficiency. As an effective supplement to traditional classroom teaching model, micro-lectures are suitable for the personalized and in-depth learning. Based on the case study of integrated English class in University of Chinese Academy of Social Sciences (UCASS), the present paper claims that the application of micro-lectures in traditional integrated English classroom greatly stimulates students' enthusiasm and interest in language learning.
\end{abstract}

Keywords: integrated English teaching, micro-lecture, application, exploration

\section{Introduction}

Integrated English is one of the core courses for English majors. The goal of it is to develop and improve students' ability to use English in a comprehensive manner. Through basic language training and text explanations and analysis in class, students will gradually expand their vocabulary, improve their reading comprehension, understand the expressions and characteristics of various styles of English, get familiar with the idiomatic sentence patterns, and possess the basic oral and written skills in English.

Traditional integrate English teaching model is centered on the teacher, the classroom, and the textbook, aiming to impart language knowledge through face-to-face classroom lectures. It usually uses class-based instruction, with the teacher as the main lecturer, emphasizing the teacher as the authority, the transmitter of knowledge, and the controller of the teaching schedule and activities, while the students are relatively passive recipients. Besides, the traditional model of integrated English teaching mostly follows the pattern of "preview-introduce-explain-exercise" of the texts, with the focus on the learning of the language vocabulary and grammar. Thus the teaching and learning environments in the class are relatively monotonous and the teaching process is relatively formulaic. Introducing micro-lecture in the traditional integrated English classroom can effectively activate the teaching atmosphere in class and greatly enhance students' interest and enthusiasm in language learning.

\footnotetext{
Acknowledgments: This paper is supported by University of Chinese Academy of Social Sciences, No. GDJY2020015.

YANG Chun, master, associate professor, School of Foreign Languages, University of Chinese Academy of Social Sciences, Beijing, China.
} 


\section{Application and Exploration of Micro-lecture in Integrated English Class}

A "micro-lecture" is a video recording of teaching and learning activities, both used inside and outside the classroom. It centers around a particular knowledge points, such as key difficulties or doubt in teaching materials. The core content of a "micro-lecture" consists of short teaching videos, as well as supporting teaching resources such as instructional design, teaching reflections, practice tests, student feedback, teacher's comments, so on and so forth. The main features of micro-lecture include:

1. Short time of teaching: The duration of a micro-lecture is generally about 5-10 minutes.

2. Concise teaching content: A micro-lecture usually focuses on one topic and the content of teaching is concise and clear.

3. Flexible and easy operation: With the help of electronic technology, it is easy and flexible for students to download the teaching videos and watch them to prepare for new knowledge, review and consolidate old knowledge, and fill in gaps and deficiencies of their own in a self-directed way. In the learning process, for the incomprehensible and difficult parts, students can watch the teaching videos repeatedly until they are understood. Exercises can also be self-selected and done in a targeted way. Students can even look up materials on the Internet to expand and extend according to their own level and different requirements of the teacher.

4. Wide range of subjects: The micro-lectures are usually made by the teachers with the purpose of arousing the students' interest of learning, thus the subjects in the micro-lectures are not only short and concise, but also of great variety.

It has been proved that the application of micro-lecture in traditional classroom teaching model enables students to arrange their time rationally, study efficiently, and develop independent learning, thus greatly changes the traditional passive learning style, and encourages students to gradually form their own learning methods. Besides, students' interest and enthusiasm in learning is effectively enhanced. As we all know, interest is the best teacher. If a student likes a subject, then his academic performance in that subject will be relatively good.

\section{A Case Study of Integrated English Class}

As a part of teaching reform project of University of Chinese Academy of Social Sciences (UCASS), in the school year of 2020, micro-lecture is introduced in integrated English class. Based on my teaching experience, I would like to share some of my own opinions on how to apply micro-lectures in integrated English class.

My students are fresh men. There are 15 students in the class. The textbook used in class is Contemporary College English Intensive Reading Book I (second edition), published by Foreign Language Teaching and Research Press, Beijing. The textbook focuses on the basic English language skills and is rich in linguistic phenomena and cultural connotations. However, through years of teaching practice, we have noticed that some of the selected texts are abstract and some contain many literary terms which are difficult for students to understand. In order to cultivate the language skills, the diversified cultural aspects, and the critical thinking and humanistic qualities of the students, based on the intensive classroom teaching, we provide students with 15 teaching videos for them to watch after class as well as some supporting reading materials to guide them in independent learning, inquiry-based learning, and collaborative learning. 
Table 1

Teaching Videos

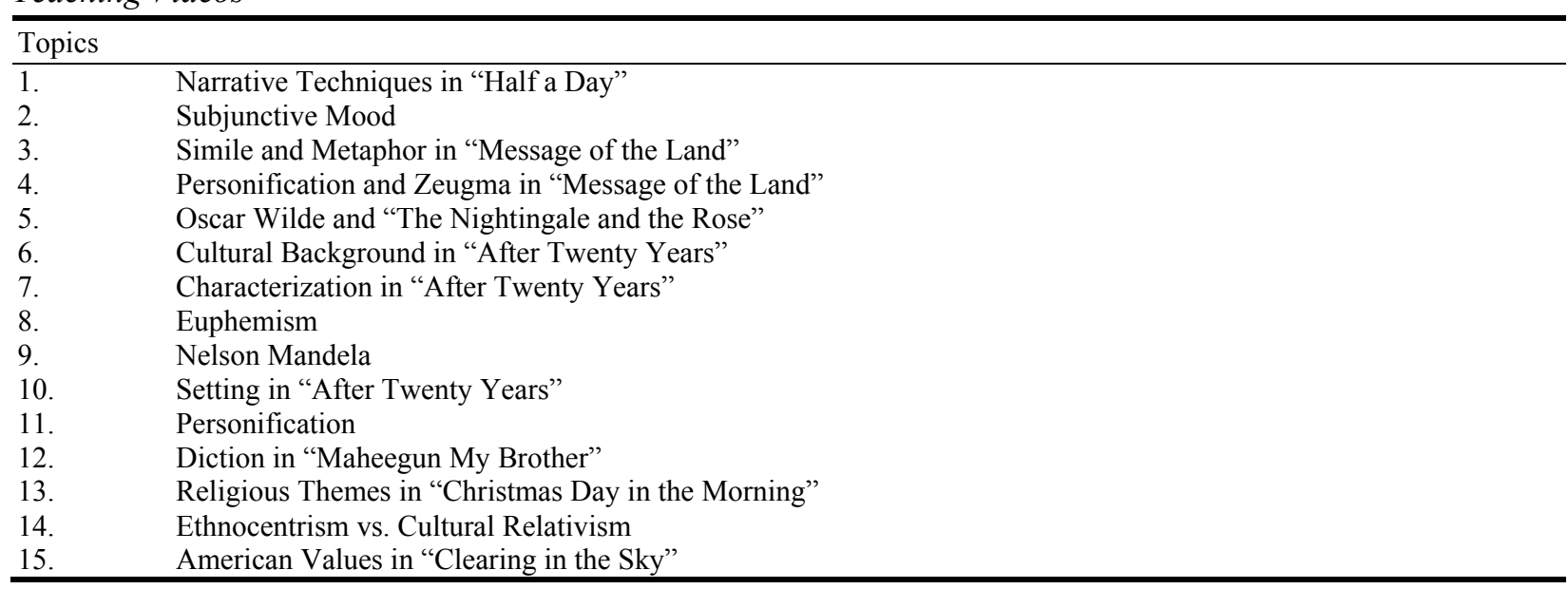

These topics covered almost all the difficult points in the texts, including the topic of figures of speech, cultural background of the texts as well as the introduction of the elements of short stories such as setting and characterization. The teaching videos are carefully designed, the content is concise and vivid, and every video clip is no less than 10 minutes. To make the teaching video clear and easy for students to watch and learn, we thoughtfully design the PPT in each teaching video. Let's take the Narrative Techniques in "Half a Day" as an example.

"Half a Day" is one of the texts in the textbook. As the winner of Nobel Prize for literature, the author of "Half a Day", Naguib Nahfouz has used many narrative techniques in this short story. One of the distinctive narrative techniques is his deft use of "narrative voice". Narrative voice tells whose eyes the reader sees a story through. When identifying the narrative voice in literature, it is important to consider the point of view and the narrator's degrees of omniscience, objectivity, and reliability. Narrative voice is a difficult literary term for students to understand. To make the idea of this literary term easily access to the students, explanations plus vivid pictures are used in the PPT. The following are some of the PPT used in the teaching video.

\section{"Narrative voice":}

Point of view is the lens

through which readers

enter the fictional world.

Point of view is divided

into three types: first, second and third person.

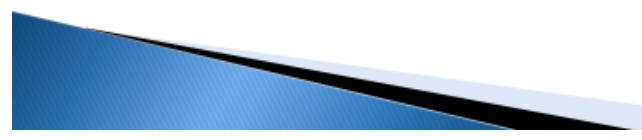




\section{The first-person point of view}

\section{A first-person narrator}

- is a character in the story

- It uses first-person pronouns such as $I$ and $m e$
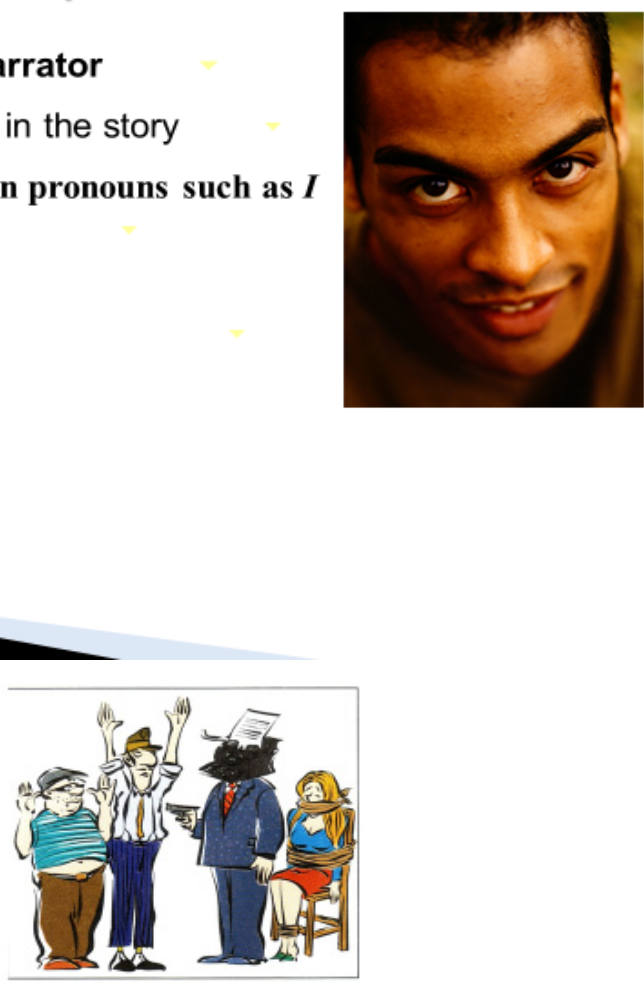

The first-person narrator can be a minor character or the protagonist. The first-person narrator has a limited point of view.

\section{First-person point of view}

Oh, man! Just as I was finally dozing off, he starts playing that stupid saxophone. I've already been fired from one job because I fell asleep on the night shift. Now it's going to happen again. I don't know which sounds worse, that tone-deaf saxophonist or that yowling dog. I'm going to call the police.
How can you

tell this is a firstperson narrator?

Do you think this narrator's opinion of the music is reliable? Why or why not? 


\section{Advantages of this POV:}

It feels natural to most writers because we live in an "l" world.

You have to deal with only one mind: the narrator's.

You can create a distinctive internal voice.

You can add an element of craft by creating a narrator who is not entirely reliable.

Disadvantages of this POV:

You are limited to writing about what the narrator can see or sense.

The narrator must constantly be on stage or observing the stage.

You can't go into the minds of other characters.

\section{Omniscient Point of View}

When the omniscient point of view is used, the narrator

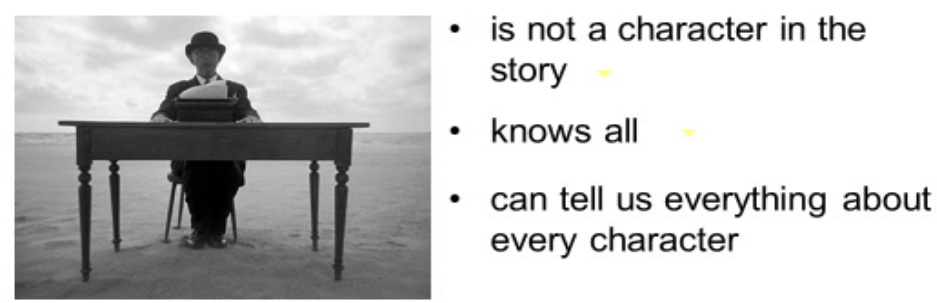




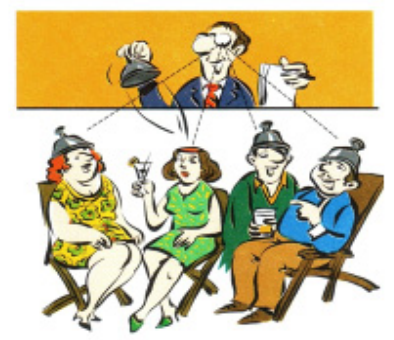

\section{The narrator is in a godlike position behind the scenes, managing the characters like puppets on strings, knowing everything.}

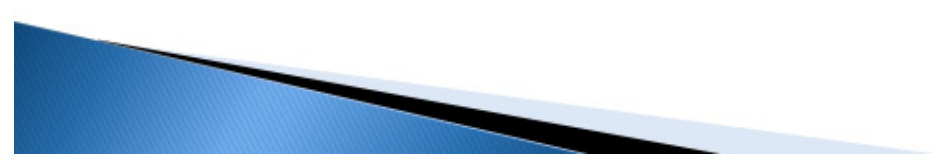

All the 15 teaching vides are shared in Cloud Classroom platform, a multi-functional teaching app. Students can download the teaching videos on their own devices, mostly cell phones or computers and watch and learn the teaching materials very conveniently.

\section{Conclusion}

In integrated English teaching, the application of micro-lectures has transformed students' learning style, increased their interest in English learning, and greatly improved their study efficiency. As an effective supplement to traditional classroom teaching model, micro-lectures are suitable for the personalized and in-depth learning. Micro-lectures provide students with a "buffet" of resources to help them understand the key concepts and skills that are difficult to master, both in the middle of the course and as a review afterwards. This type of miniature course is effective because it focuses the student's attention on a single topic for a short period of time, reducing the chance of distraction. In a word, the application of micro-lectures in integrated English class greatly stimulates students' enthusiasm and interest in language learning.

\section{References}

Cook, V. (2000). Second language learning and language teaching. Beijing: Foreign Language Teaching and Research Press.

Elbow, P. (2000). Everyone can write: Essays towards a hopeful theory of writing and teaching writing. Oxford: Oxford University Press.

Gardner, R. C., \& Lambert, W. E. (1959). Motivation variables in second language acquisition. Canadian Journal of Psychology, $13(4), 266-272$.

Haley, M. H. (2006). Content-based second language teaching and learning: An interactive approach. London: Pearson Education, Inc.

Jordan, G. (2004). Theory construction in second language acquisition. Amsterdam: John Benjamins Publishing Company.

Long, M. H., \& Richards, J. C. (Eds.). (1987). Methodology in TESOL: A book of readings. Heinle.

Macaro, E. (2001). Learning strategies in foreign and second language classrooms. New York: Continuum International Publishing Group.

Prichard, K. W., \& McLaran Sawyer, R. (Eds.) (1994). Handbook of college teaching: Theory and applications. Santa Barbara, California: Greenwood Press. 